\title{
Design and Optimization of a Photovoltaic Canopy for an Electric Vehicle Charging Station in Urban Environments
}

\author{
Dolores Parras-Burgos ${ }^{1(\otimes)}$, Jesús Melgarejo-Teruel ${ }^{1}$, Antonio Mateo-Aroca ${ }^{2}$, \\ Daniel G. Fernández-Pacheco ${ }^{1}$, Francisco J. F. Cañavate ${ }^{1}$, \\ and Francisco L. Sáez-Gutiérrez ${ }^{1}$ \\ 1 Departamento de Estructuras, Construcción y Expresión Gráfica, \\ Universidad Politécnica de Cartagena, Cartagena, Spain \\ dolores.parras@upct.es \\ 2 Departamento de Automática, Ingeniería Eléctrica y Tecnología Electrónica, \\ Universidad Politécnica de Cartagena, Cartagena, Spain
}

\begin{abstract}
Nowadays, the use of renewable energies and electric vehicles has become particularly relevant in order to lower the high pollution levels surrounding our cities. The design of a photovoltaic canopy for charging electric vehicles is a highly promising combination that can be set up in urban areas. To favour installing them in different places, this communication provides details of the technicofunctional aspects that have been considered to design and fit them, along with other aesthetic and user-centred aspects that help stimulate our society to use such infrastructures.
\end{abstract}

Keywords: Renewable energy · User-centered design · Aesthetics

\section{Introduction}

Canopies tend to be installed to protect users from adverse climate effects, like sun, snow or wind. They are employed in many places, such as entrances to buildings, bars or restaurants, car parks or public transport stops. The main use of canopies specifically employed for parked vehicles is to protect users from the sun and to avoid high temperatures inside vehicles. One way of putting this energy to good use is the socalled "photovoltaic canopies", whose roofing is covered by photovoltaic panels that allow solar energy to be absorbed and employed in several ways (Alghamdi et al. 2017; Bushur et al. 2019; Umer et al. 2019; Zarcone et al. 2016). One such use is charging electric vehicles, which are becoming particularly relevant for society that wishes to use less polluting energies. The design of such installations must provide urban area with places that promote this energy type. So an aesthetic user-centred design is just as important as technico-functional aspects that have been considered to build them (De Fusco 1981; Gay and Samar 2004; Macdonald 2001; Parras-Burgos et al. 2019).

This communication presents an optimised photovoltaic canopy design for charging electric vehicles. This novel proposal presents a system that not only supplies part of the 
energy required for charging electric vehicles with renewable energy, but also supplies users with an attractive and convenient rest area while they wait.

\section{Materials and Methods}

To design and set up such installations, the regulations and characteristics of each area must be taken into account. The study presented in this communication was conducted for an area in Murcia (Spain), but can be extrapolated elsewhere. The proposed photovoltaic canopy would be formed by four parking spaces with charging points for electric vehicles. Its structure has a span of 5,9 m, is $12,2 \mathrm{~m}$ long with two openings, and users can freely move around the rest area. Bearing in mind the location of this installation, the optimum slope of the photovoltaic panels would be $30^{\circ}$. However, adapting these layouts to the metal structure implies considerably concentrating stresses. This is why a slope of $15^{\circ}$ was set by assuming loss of the photovoltaic installation's power (Fig. 1).

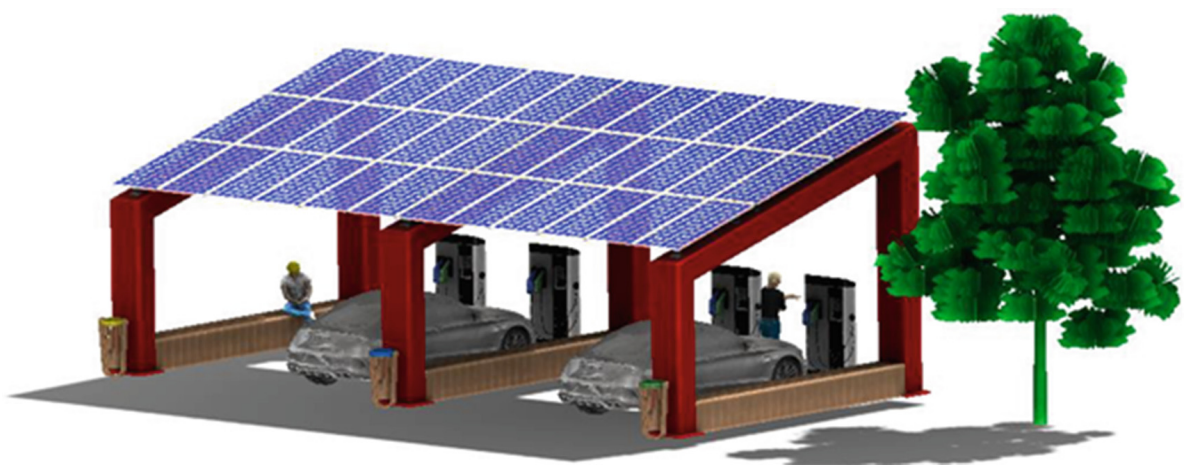

Fig. 1. General view of the photovoltaic canopy as an electric vehicle-charging station.

In order to provide this type of canopies distinguishing aesthetics and to extend their functionality, trapezoidal single-pitch gantries were designed with two pillars measuring $4.396 \mathrm{~m}$ and $2.815 \mathrm{~m}$ respectively, with an upper lintel on which two roof purlins rest, and a lower one to act as the rest area for waiting while charging cars. These rest areas include wooden seating to make the area welcoming and comfortable (Fig. 2). The aesthetic and user-centered design aspects that stand out from this model are its large surfaces for customer use, combining various colors and materials that give the whole a feeling of resistance and comfort.

The most economic separation among frames to meet economic criteria should not exceed $5 \mathrm{~m}$ or $6 \mathrm{~m}$. This measure is to reduce manufacturing costs (the structure's weight, labour, assembly, etc.) and to make full use of the length of the bars forming the crosssections that act as purlins (usually about $12 \mathrm{~m}$ long). The structure's sizes will meet these criteria if this aspect is taken into account.

To streamline, and to consequently lower the main metal structure's cost, standard rolled steel cross-sections are used, whose design was studied to achieve mechanical 


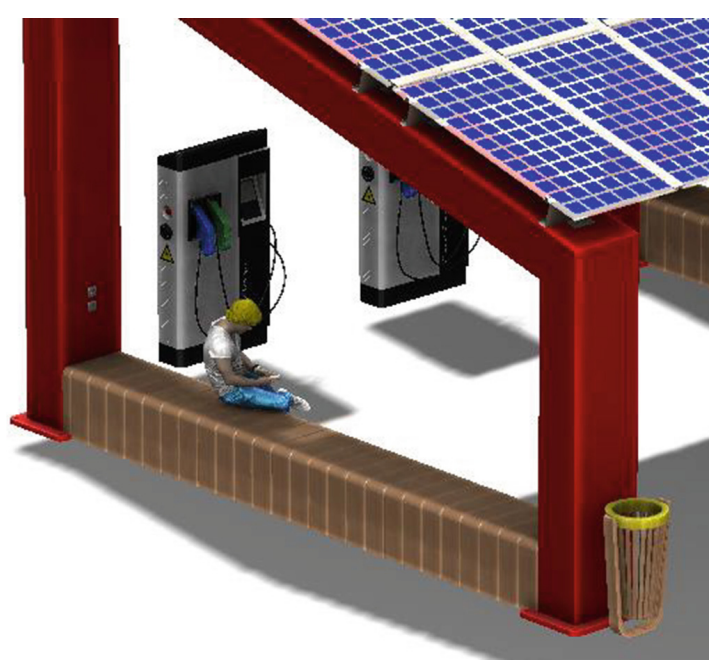

Fig. 2. Details of the rest area

efficiency and economic materials. For the purlins, we chose to use formed steel given the importance of its function in photovoltaic installations.

The self-service photovoltaic installation design is made up of the following elements:

- Photovoltaic panels: they produce electric energy from solar energy and have their own electric protection.

- Support structure: a canopy that acts as a structure for the photovoltaic panels to rest on.

- Inverter: a device that transforms the direct current produced in the photovoltaic panels into suitable alternating current to be used.

- Generated energy counter: measuring equipment that controls the energy generated by the photovoltaic installation.

- Connection to the distribution network, along with its protections.

- Other supplementary fittings: wiring, protector boxes, etc.

The photovoltaic panels cover the top of the canopy structure and act as roofing. The panel model to be used is SI-ESF-M-BIPV-SM-P156-72 from the SOLAR INNOVA company. This is a BIPV (Building Integrated PhotoVoltaic) panel model so that the photovoltaic generator can be completely built into the structure. Its main mechanic and electric features are shown in Table 1.

One very important aspect when streamlining photovoltaic installations is limiting the spaces restricted by a canopy's sizes. This is why a 36-panel photovoltaic generating system with $11,7 \mathrm{~kW}$ power was designed in relation to charging powers, which also adapts to the available sizing to be installed.

The inverter's power is determined by the photovoltaic generator's nominal power under standard test conditions (STC) by considering the inverter's performance and 
Table 1. The main properties of the SI-ESF-M-BIPV-SM-P156-72 photovoltaic panel from the SOLAR INNOVA company.

\begin{tabular}{l|l}
\hline Magnitude & Value \\
\hline Sizes & $1.948 \times 976 \times 30(\mathrm{~mm})$ \\
\hline Weight & $29 \mathrm{~kg}$ \\
\hline Maximum power voltage $(\mathrm{Vmpp})$ & $38,1(\mathrm{~V})$ \\
\hline Open-circuit voltage $(\mathrm{Voc})$ & $46,7(\mathrm{~V})$ \\
\hline Maximum power current $(\mathrm{Impp})$ & $8,53(\mathrm{~A})$ \\
\hline Short-circuit current $(\mathrm{Icc})$ & $9,07(\mathrm{~A})$ \\
\hline Maximum power rating $(\mathrm{Pmpp})$ & $325(\mathrm{~W})$ \\
\hline
\end{tabular}

the power loss factors of the photovoltaic modules under real operating conditions. We decided to fit two inverters whose sizes allow the equipment to be built into the canopy's framing and to achieve its best aesthetic integration. The chosen inverter model is the three-phase Fronius Symo 5.0-3-M with its flexible design, whose sizes enable it to be included in the canopy (Table 2). A three-phase inverter was selected to facilitate its connection to the three-phase electric vehicle-charging installation and to avoid any type of imbalance among phases.

Table 2. Characteristics of the three-phase Fronius Symo 5.0-3-M inverter model's input/output.

\begin{tabular}{l|l|l|l}
\hline Input & Value & Output & Value \\
\hline Maximum generated power FV & Peak $10 \mathrm{~kW}$ & Nominal power & $5 \mathrm{kw}$ \\
\hline Voltage range MPP & $163-800 \mathrm{~V}$ & Maximum temperature & $60^{\circ} \mathrm{C}$ \\
\hline Maximum input voltage & 1000 & Maximum current & $7,2 \mathrm{~A}$ \\
\hline Maximum input current & $16 \mathrm{~A}$ & Nominal voltage & $400 \mathrm{~V}$ \\
\hline Direct current & $24 \mathrm{~A}$ & Nominal frequency & $50 / 60 \mathrm{~Hz}$ \\
\hline No. Inputs & $2+2$ & Network type & $\mathrm{TT} / \mathrm{T}$ \\
\hline & & Performance & $97,9 \%$ \\
\hline
\end{tabular}

The Fronius inverter includes a Fronius Smart Meter. This equipment sends the most complete data to the monitoring system and does not allow the inverter to inject energy into the electric network. In line with the features of the inverter selected as the employed panels' characteristics, 18 panels were placed in series to form a chain.

The RAPTION-22 model was chosen as the electric vehicles-charging system to allow vehicles to be quickly charged whenever required and there is not enough power. Depending on their capacity, batteries can be partially or completely charged in short times. The RAPTION-22 station operates with powers up to $22 \mathrm{~kW}$, which means it can be fitted in simpler installations and saves extra costs related to special rates. This 
device has an interactive screen, and communications (Ethernet, $3 \mathrm{G}$ ) that facilitate users' interaction, as well as remote management to the control centre. This selected product permits two charge types, direct current (DC) and alternating current (AC), so it adapts to the charging system of any vehicle on the market. This means that it has connectors CHAdeMO and CCS Combo 2 in DC and type 2 Mennekes in AC. It also allows three-phase and single-phase currents (Table 3).

Table 3. Characteristics of input in AC, output in DC and output in AC of the RAPTION 22 charging station.

\begin{tabular}{l|l|l|l|l|l}
\hline Input AC & Value & Output DC & Value & Output AC & Value \\
\hline AC supply & $3 \mathrm{~F}+\mathrm{N}+\mathrm{PE}$ & $\begin{array}{l}\text { Maximum } \\
\text { output current }\end{array}$ & $56 \mathrm{Acc}$ & $\begin{array}{l}\text { Maximum } \\
\text { output current }\end{array}$ & $32 \mathrm{~A}$ \\
\hline $\begin{array}{l}\text { AC voltage } \\
\mathrm{CA}\end{array}$ & $400 \mathrm{Vac} \pm 10 \%$ & $\begin{array}{l}\text { Maximum } \\
\text { output power }\end{array}$ & $22 \mathrm{~kW}$ & $\begin{array}{l}\text { Maximum } \\
\text { output power }\end{array}$ & $22 \mathrm{~kW}$ \\
\hline $\begin{array}{l}\text { Current } \\
\text { nominal input }\end{array}$ & $64 \mathrm{~A}$ & $\begin{array}{l}\text { Range of } \\
\text { output voltage }\end{array}$ & $150-550 \mathrm{Vcc}$ & $\begin{array}{l}\text { Range of } \\
\text { output voltage }\end{array}$ & $400 \mathrm{Vca}$ \\
\hline $\begin{array}{l}\text { Power factor } \\
\text { Efficiency }\end{array}$ & 90.98 & & & & \\
\hline Frequency & $50 / 60 \mathrm{~Hz}$ & & & & \\
\hline
\end{tabular}

The total cost of the system taking into account foundations, structures (pillars, light structures for roofs and beams) and installations (grounding, pipes, cables, protection boxes, photovoltaic solar modules and electric vehicle charging stations) amounts to $185.052 €$.

\section{Conclusions}

One area where electric vehicles will be very important is urban areas because electric vehicles do not emit direct polluting emissions. It is here where not only the structure's functionality and installations are important, but also its aesthetics and design. Installing canopies in cities to quickly charge electric vehicles is becoming a very effective solution, provided the structure can be integrated into the domain it is located in. Accordingly, the proposed canopy design can be classified as a canopy with a strong visual impact and a completely built in photovoltaic system. It strikes the best balance between energy efficiency and its architectural integration into its surroundings. The main advantage of this vehicle-charging canopy is that energy is produced in the same place where it is used, which avoids resorting to lengthy energy transports and substantially enhances the system's total efficiency. For this reason, this installation fulfils the described objectives: an integrating and optimised structure that is functional, modular and user-centred that adapts to any location. 


\section{References}

Alghamdi, A.S., Bahaj, A.S., Wu, Y.: Assessment of large scale photovoltaic power generation from carport canopies. Energies 10(5) (2017). https://doi.org/10.3390/en10050686

Bushur, A., Ward, K., Flahaven, T., Kelly, T., Jo, J.H., Aldeman, M.: Techno-economic evaluation of installing EV and PV combined infrastructure on Academic Institution's Parking Garages in Illinois, USA. AIMS Energy 7(1), 31-45 (2019). https://doi.org/10.3934/energy.2019.1.31

De Fusco, R.: Historia de la arquitectura contemporánea: H. Blume Ediciones (1981)

Gay, A., Samar, L.: El diseño industrial en la historia. Ediciones Tec., Córdoba, Argentina (2004)

Macdonald, A.S.: Aesthetic intelligence: optimizing user-centred design. J. Eng. Des. 12(1), 37-45 (2001). https://doi.org/10.1080/09544820010031562

Parras-Burgos, D., Hernández, J., Velázquez, J., Cavas-Martínez, F., Cañavate, F., FernándezPacheco, D.: Combined urban furniture designed by a bio-inspired approach. In: Advances on Mechanics, Design Engineering and Manufacturing II, pp. 564-572. Springer (2019)

Umer, F., Aslam, M.S., Rabbani, M.S., Hanif, M.J., Naeem, N., Abbas, M.T.: Design and optimization of solar carport canopies for maximum power generation and efficiency at Bahawalpur. Int. J. Photoenergy 2019 (2019). https://doi.org/10.1155/2019/6372503

Zarcone, R., Brocato, M., Bernardoni, P., Vincenzi, D.: Building Integrated Photovoltaic System for a Solar Infrastructure: liv-lib' project. Paper presented at the Energy Procedia (2016)

Open Access This chapter is licensed under the terms of the Creative Commons Attribution 4.0 International License (http://creativecommons.org/licenses/by/4.0/), which permits use, sharing, adaptation, distribution and reproduction in any medium or format, as long as you give appropriate credit to the original author(s) and the source, provide a link to the Creative Commons license and indicate if changes were made.

The images or other third party material in this chapter are included in the chapter's Creative Commons license, unless indicated otherwise in a credit line to the material. If material is not included in the chapter's Creative Commons license and your intended use is not permitted by statutory regulation or exceeds the permitted use, you will need to obtain permission directly from the copyright holder.

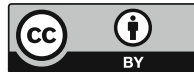

